\title{
Contemporary Issues in Psychological Sciences
}

Review Article

Abdullah MQ*

Professor, Clinical psychology, Faculty of Education, University of Aleppo, Syria.

Psychology is the science of behavior and mind. Psychology includes the study of conscious and unconscious phenomena, as well as feeling and thought. It is an academic discipline of immense scope. Psychologists seek an understanding of the emergent properties of brains, and all the variety of phenomena linked to those emergent properties, joining this way the broader neuroscientific group of researchers. As a social science it aims to understand individuals and groups by establishing general principles $[4,5]$.

Major schools of psychology are the Biological, Cognitive, behavioral, social, psychoanalysis, and existential-humanistic theories/approaches. The most important themes include: motivation, emotions, cognition, personality, unconscious processes development and genes and environment. On the other hand, there are many research methodologies for investigating these themes, such as: experimental and statistical method, technological, computer methods, animal studies, qualitative and descriptive researches, clinical methods, longitudinal-developmental researches, comparative methods [1].

Recently, the most significant and critical issues in researching and investigating the behavior relating to the methodology and the type of studies that have been used.

I can summarize the critical issue by devising the strategies and then methodology into two trends: Naturalistic-empirical and humanistic-clinical approaches.

The efforts of psychologists and clinicians can be related relatively, to one of these strategies regarding the subjects/themes on one hand, and the methodology on the other hand.

I can distinguish between the variables of these trends and strategies as the following:

\begin{tabular}{|l|l|l|}
\hline Variable & Naturalistic-experimental trend & Humanistic-clinical trend \\
\hline Main field & $\begin{array}{l}\text { Experimental psychology } \\
\text { General psychology and normal personality) }\end{array}$ & $\begin{array}{l}\text { Clinical psychology } \\
\text { (Abnormal psychology \& personality) }\end{array}$ \\
\hline Subjects/themes & General - mental processes & Behavioral problems \\
\hline Awareness & Consciousness & Unconsciousness \\
\hline Experience & Observing the external behavior & Alive - experiences \\
\hline Parts/whole & Parts before whole & Whole before parts \\
\hline Correlations & Quantitative correlations & Qualitative correlations \\
\hline Facts & Physical facts & Human/spiritual facts \\
\hline The purpose and the values & Reject the subjective & Accept the subjective \\
\hline Comparative & Comparative with animals & Comparative inter-and intra- individuals \\
\hline Controlling variables & High & Low \\
\hline Difficulties & $\begin{array}{l}\text { More Limitations and difficulties of manipu- } \\
\text { lating the subjects of behavior }\end{array}$ & $\begin{array}{l}\text { Low limitations and difficultiesof manipulat- } \\
\text { ing the behavior }\end{array}$ \\
\hline Accuracy & Scientific accuracy & Lack of scientific accuracy \\
\hline Stubbornness & High Rigidity \& stubbornness & Low rigidity \\
\hline Tests and measurement & Whole indications & Partial indications among Whole personality \\
\hline
\end{tabular}

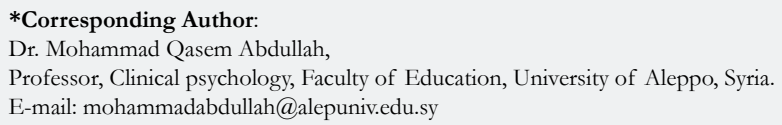


In sum, Ethical standards in the discipline have changed over time [3]. Current ethical guidelines state that using non-human animals for scientific purposes is only acceptable when the harm (physical or psychological) done to animals is outweighed by the benefits of the research. Keeping this in mind, psychologists can use certain research techniques on animals that could not be used on humans.

The theme/subjects of psychology is behavior, but the human behavior is more complex for investigating, and the multi-methodologies are very significant for good understanding, controlling and predicting behavior [2].

\section{References}

[1]. Abdullah,M.(2012). Theories of psychological counseling. University of Aleppo press. Aleppo, Syria.

[2]. Abdullah QM. Introduction to mental health. Dar Alfikr: Amman. 2016.

[3]. Abdullah, M.(2019). Ethics of scientific research. Paper submitted to the national committee of The ethics of sciences and technology. Syria.

[4]. Fernald LD.Psychology: Six perspectives Thousand Oaks, CA: Sage Publications. $2008 ; 12-15$.

[5]. Hockenbury DH, Hockenbury SE. Discovering psychology. Macmillan. 2010 . 